ZOOLOGIA 28 (6): 755-761, December, 2011

doi: $10.1590 /$ S1984-46702011000600008

\title{
Seasonal variation in the leaf-litter frog community (Amphibia: Anura) from an Atlantic Forest Area in the Salto Morato Natural Reserve, southern Brazil
}

\section{Manuela Santos-Pereira',4; Adriane Candaten²; Douglas Milani³; Frederico B. Oliveira ${ }^{2}$; Joana Gardelin² \& Carlos F. D. da Rocha ${ }^{1}$}

\author{
${ }^{1}$ Departamento de Ecologia, Instituto de Biologia Roberto Alcântara Gomes, Universidade do Estado do Rio de Janeiro. \\ Rua São Francisco Xavier 524, 20550-013 Rio de Janeiro, RJ, Brazil. \\ ${ }^{2}$ Curso de Ciências Biológicas, Instituto de Ciências Biológicas, Universidade de Passo Fundo. Campus I, Rodovia BR 285, \\ 99001-970 Passo Fundo, RS, Brazil. \\ ${ }_{3}^{3}$ Parque Nacional da Serra dos Órgãos. Avenida Rotariana, Soberbo, 25960-602 Teresópolis, RJ, Brazil. \\ ${ }^{4}$ Corresponding author. E-mail: herpeto.pereira@gmail.com
}

\begin{abstract}
In this study we provide the first data regarding community parameters of leaf-litter anurans inhabiting a forest floor in the state of Paraná, southern Brazil, including information on community species richness, composition, specific density and biomass. Our study was conducted at Salto Morato Natural Reserve using forty plots of $4 \times 4 \mathrm{~m}$ for each one of the four seasons (winter, spring, summer and autumn), totaling $2.560 \mathrm{~m}^{2}$ of forest floor sampled. We sampled a total of 96 frogs inhabiting the forest floor, belonging to seven species: Brachycephalus hermogenesi (Giaretta \& Sawaya, 1998), Ischnocnema guentheri (Steindachner, 1864), Haddadus binotatus (Spix, 1824), Leptodactylus gr. marmoratus, Physalaemus spiniger (Miranda-Ribeiro, 1926), Proceratophrys boiei (Wied-Neuwied, 1824), and Rhinella abei (Baldissera, Caramaschi \& Haddad, 2004). The overall frog density in the forest floor was 3.73 ind $/ 100 \mathrm{~m}^{2}$, with I. guentheri $\left(1.37 \mathrm{ind} / 100 \mathrm{~m}^{2}\right)$ being the most common species and $R$. abei $\left(0.19 \mathrm{ind} / 100 \mathrm{~m}^{2}\right)$, the rarest. The estimated overall frog mass in the community was $3.29 \mathrm{~g}$. The abundance, richness and density varied consistently among the four seasons sampled, with the highest values occurring in the spring and summer seasons.
\end{abstract}

KEY WORDS. Atlantic Rainforest; density; richness; seasonality.

Habitat reduction and degradation, especially in tropical forest areas, has caused a worrisome global loss of species (Benítez-Malvido \& Martínez-Ramos 2003, Gardner et al. 2007, Todd \& ANDrews 2007). The Brazilian Atlantic Forest has a high biodiversity and high endemism rates, sheltering approximately $7 \%$ of the world's plant and animal species. Due to human action, it is among the most threatened biomes, with only about $12 \%$ of the original area remaining (QUINTELA 1990, Myers et al. 2000, Ribeiro et al. 2009). Regarding amphibians, Brazil is the most species rich country, reaching almost 900 recognized species (SBH 2010). Only in the Atlantic Rainforest Biome, there are more than 400 registered amphibian species, with most of them endemic to this biome (HADDAD et al. 2008).

Several studies carried out in different tropical forests throughout the world provide data on richness, composition and density of frogs living on the leaf-litter layer of the forest floor (e.g., Brown \& Alcala 1961, ScotT 1976, 1982, Fauth et al. 1989, Allmon 1991, GASCON 1996). However, for the Atlantic Rainforest, there are few studies providing data on leaf-litter frog species composition and richness (HEYER et al. 1990, HADDAD \& Sazima 1992, Giaretta et al. 1997, 1999, Machado et al. 1999, Rocha et al. 2000, 2001, Роmbal \& GoRdo 2004, Rocha et al. 2007, SIQUEIRA et al. 2009). Only seven studies present data on relative densities of frogs in leaf litter communities already studied (Giaretta et al. 1997, 1999, Rocha et al. 2000, 2001, 2007, Almeida-Gomes et al. 2008, Siqueira et al. 2009).

The species composition and abundance of leaf-litter frogs can be influenced by several factors, such as altitudinal gradients (Brown \& Alcala 1961, Fauth et al. 1989, Giaretta et al. 1999) and seasons (Scott 1976, Giaretta et al. 1999, Vonesh 2001). Although studies of leaf-litter frog communities in tropical forests are continuously increasing during recent years within Brazil (e.g., AlmeIdA-Gomes et al. 2008, Siqueira et al. 2009), only one study discusses the effects of seasonality on the parameters of these communities (GIARETTA 1999). The same gap of knowledge regarding seasonal trends in the leaf litter frog communities is observed worldwide, with only a few available studies in Central America (Toft 1980a, Watling \& Donnelly 2002) and Asia (Watanabe et al. 2005). 
In this paper, we study the influence of seasonality on the community parameters, such as abundance, richness and density, of leaf-litter frogs in the Salto Morato Nature Reserve. We also compared these values to others forests in Brazil and worldwide. To our knowledge, this study is the first one providing information regarding community parameters of leaflitter anurans inhabiting a forest floor in the state of Paraná, southern Brazil.

\section{MATERIAL AND METHODS}

The study was carried out in the Reserva Particular do Patrimônio Natural Salto Morato $\left(25^{\circ} 09^{\prime} \mathrm{S}, 48^{\circ} 16^{\prime}\right.$ a $\left.48^{\circ} 20^{\prime} \mathrm{W}\right)$, municipality of Guaraqueçaba, state of Paraná, southern Brazil. The area, with 2.340 ha, is located within the Área de Preservação Ambiental de Guaraqueçaba, which is part of the largest currently existing remnant of Atlantic Rainforest in Brazil (FunDAÇÃO SOS MATA AtLÂNTICA 1998). The average annual temperature is $21^{\circ} \mathrm{C}$. The rainfall rates are high, with more than $2,000 \mathrm{~mm}$ per year and annual average relative air humidity is $85 \%$. The altitude varies between 25-930 m. (FBPN 1995) (Fig. 1).

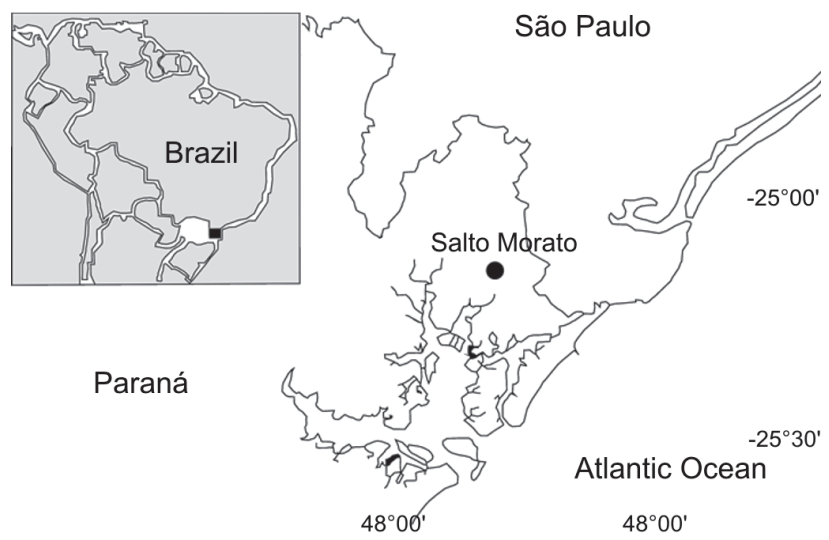

Figure 1. Location of the study area: Reserva Natural Salto Morato, Guaraqueçaba. Source: Straube \& URben-Filho (2005).

Four surveys were conducted from July 2009 to April 2010, with sampling every three months, covering the four seasons (winter, spring, summer and autumn), in a forest belt, located between 200 and $300 \mathrm{~m}$ of altitude. To sample the community of frogs we used the large-plot method sampling (RоснA et al. 2001). We established 160 quadrants of $4 \times 4 \mathrm{~m}$ on the forest floor, totaling 2,560 $\mathrm{m}^{2}$ of area sampled for the whole study. The corners of each plot were marked with wooden stakes and the plot was completely surrounded by a $50 \mathrm{~cm}$ high screen. The screen was buried in the ground to prevent the frogs from escaping. Air temperature $\left({ }^{\circ} \mathrm{C}\right)$ and air humidity (\%) were determined prior to sampling a certain plot. After sunset, each plot was carefully reviewed by a team of four researchers using head lamps. During searches, the crew moved up the entire plot on hands and knees, side-by-side. All leaves, fallen branches and stones inside the plot were overturned and the crevices of rocks and spaces between the roots of trees were checked, searching for frogs. Searches in each plot lasted about half an hour.

Frogs found were collected, identified and deposited in the Museu de História Natural Capão da Imbuia, Curitiba, state of Paraná, and in the Museu Nacional, Rio de Janeiro, state of Rio de Janeiro. Snout-vent length (SVL in $\mathrm{mm}$ ) of all frogs were measured using a digital caliper; individual body mass (to the nearest $0.1 \mathrm{~g}$ ) was obtained using a Pesola dynamometer.

The ordination was based on a Bray-Curtis dissimilarity matrix of ecological distance (FAITH et al. 1987). Density (ind/ $100 \mathrm{~m}^{2}$ ) and biomass ( $\mathrm{g} / \mathrm{ha}$ ) were estimated for each frog species each season. The composition of community of leaf-litter frogs among seasons was analyzed using non-metric multidimensional scaling (NMDS) (CLARKe 1993). The effect of variables (temperature and air humidity) on the parameters of the community of leaf-litter frogs was evaluated by regression analysis (ZAR 1984). Both tests were performed in SYSTAT 11.0 (WILKINSON 2004).

\section{RESULTS}

We recorded seven frog species associated with the leaflitter of the forest floor in Reserva Salto Morato: Ischnocnema guentheri (Steindachner, 1864), Brachycephalus hermogenesi (Giaretta \& Sawaya, 1998) (Brachycephalidae), Leptodactylus gr. marmoratus (Leptodactylidae), Physalaemus spiniger (MirandaRibeiro, 1926) (Leiuperidae), Proceratophrys boiei (WiedNeuwied, 1824) (Cycloramphidae), Haddadus binotatus (Spix, 1824) (Craugastoridae), and Rhinella abei (Baldissera, Caramaschi \& Haddad, 2004) (Bufonidae) (Tab. I).

In 160 plots sampled, the plots percentage without frogs was $52 \%$ and the average of frogs per plot was 1.6. The composition and density of the leaf-litter frogs in the community varied among seasons, with the highest values in spring and summer seasons (Tab. I, Fig. 2). The air temperature affected significantly the overall frog abundance $\left(\mathrm{R}^{2}=0.098, \mathrm{~F}_{1,143}=\right.$ $15.513, \mathrm{p}<0,001)$ in local community. The moisture, in contrast, did not affect overall frog abundance $\left(\mathrm{R}^{2}=0.001, \mathrm{~F}_{1,143}=\right.$ $0.082, \mathrm{p}=0.774)$. The NMDS showed a clustering of summer and spring, although there was no grouping between winter and autumn (Fig. 3).

Considering all seasons combined, the estimated overall frog density of the leaf-litter frog community the Reserva Salto Morato was 3.73 ind $/ 100 \mathrm{~m}^{2}$ (Tab. I). Ischnocnema guentheri had the highest abundance and density in three of the four seasons sampled (winter, $\mathrm{N}=5,0.78$ ind $/ 100 \mathrm{~m}^{2}$; spring, $\mathrm{N}=13,2.03$ ind $/ 100 \mathrm{~m}^{2}$ and summer, $\mathrm{N}=14,3.44 \mathrm{ind} / 100 \mathrm{~m}^{2}$ ), while $L$. gr. marmoratus had the highest abundance $(\mathrm{N}=6)$ and density $\left(0.94 \mathrm{ind} / 100 \mathrm{~m}^{2}\right)$ in autumn (Tab. I). The lower abundance $(\mathrm{N}=1)$ and density $\left(0.16\right.$ ind $\left./ 100 \mathrm{~m}^{2}\right)$ was recorded for $B$. 
hermogenesi in the winter, $H$. binotatus and $R$. abei during the spring, B. hermogenesi and $R$. abei in summer and $H$. binotatus and $B$. hermogenesi during autumn (Tab. I).

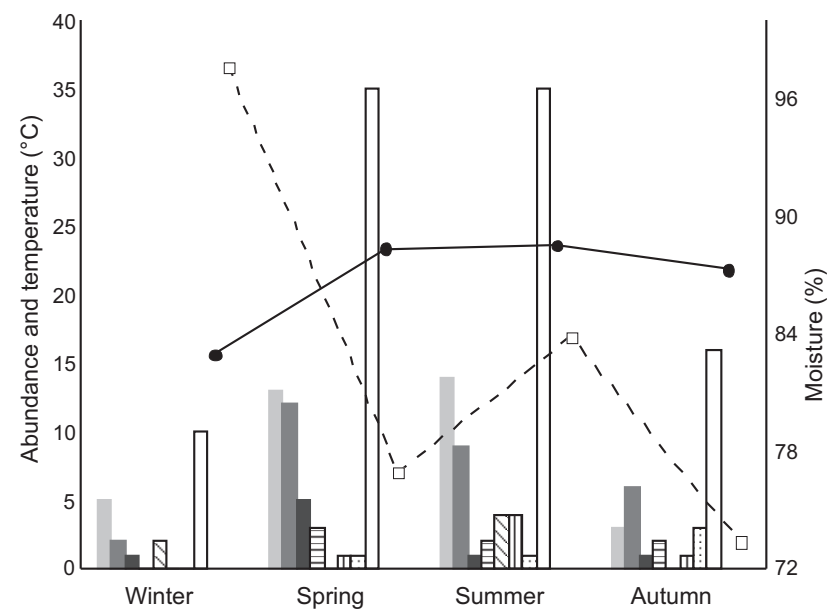

Figure 2. Temperature, moisture and abundances (specific and overall) of leaf-litter frogs during the four seasons sampled in the Reserva Natural Salto Morato, Guaraqueçaba. Ischnocnema guentheri = light gray bars, L. marmoratus = gray bars, $B$. hermogenes $i=$ dark gray bars, $P$. spiniger $=$ bars with horizontal lines, $P$. boiei $=$ bars with diagonal lines, $H$. binotatus $=$ bars with vertical lines, $R$. abei $=$ bars with points and Overall $=$ white bars. Temperature $=$ solid lines and moisture $=$ dotted lines .

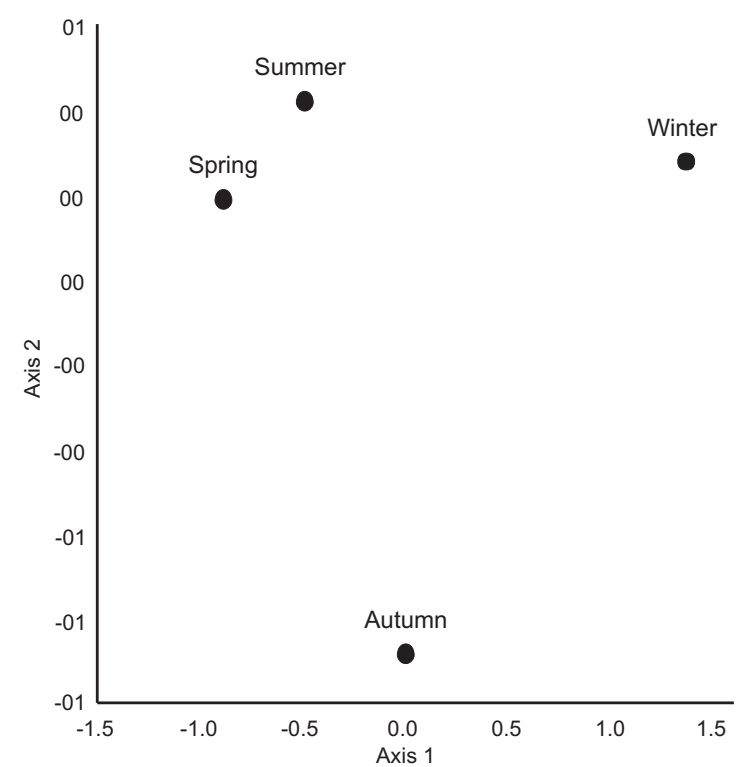

Figure 3. NMDS ordination indicating the community composition of leaf-litter frogs during the four seasons sampled in the Reserva Natural Salto Morato, Guaraqueçaba. Stress $=0$.

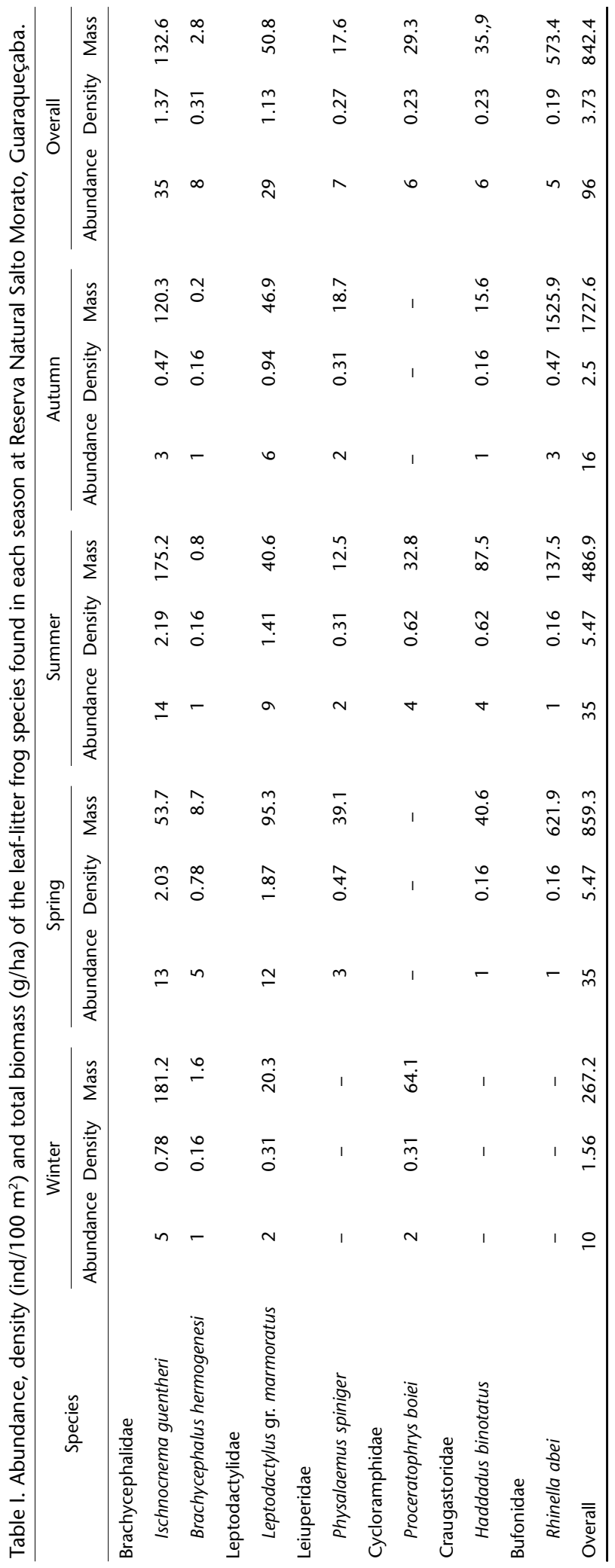

ZOOLOGIA 28 (6): 755-761, December, 2011 
The seven species recorded in the leaf-litter frog community of Reserva Salto Morato showed differences in biomass among seasons. The overall frogs mass recorded in the community of leaf-litter frogs at Salto Morato Reserve was $842.4 \mathrm{~g} /$ ha (Tab. I).

In terms of frog biomass in the community, Ischnocnema guentheri was the frog presenting the highest mass during the winter $(181.2 \mathrm{~g} / \mathrm{ha})$ and summer $(175.2 \mathrm{~g} / \mathrm{ha})$, while biomass of $R$. abei dominated during spring and autumn. The lowest biomass in the four seasons sampled was from the species B. hermogenesi (winter $=1.6 \mathrm{~g} / \mathrm{ha}$, spring $=8.7 \mathrm{~g} / \mathrm{ha}$, summer $=$ $0.8 \mathrm{~g} / \mathrm{ha}$ and autumn $=0.2 \mathrm{~g} / \mathrm{ha}$ ) $($ Tab. I) .

\section{DISCUSSION}

The species richness of leaf-litter frogs (seven species) observed in Salto Morato forest can be considered relatively low when compared with some other Atlantic Rainforest areas, such as the forests in the states of Rio de Janeiro (Reserva Ecológica de Guapiaçu, Cahoeiras de Macacu Municipality = 12 species, Rocha et al. 2007; Parque Estadual dos Três Picos, Cahoeiras de Macacu Municipality = 16 species, Siqueira et al. 2009) and São Paulo (Parque Florestal do Itapetinga, Atibaia Municipality = 16 species, GiaretTa et al. 1999).

In the Atlantic Rainforest biome, there are latitudinal differences regarding biological diversity for different animal groups (Rocha et al. 2007). Along the large latitudinal range of the biome (from $5^{\circ}$ to $30^{\circ} \mathrm{S}$ ), species diversity and rates of endemism tend to be higher in its "middle portion" (states of Rio de Janeiro, Espírito Santo, eastern São Paulo and southeastern Minas Gerais) for lizards (VAnzolini 1988), birds (ScotT \& Brooke 1985, Collar et al. 1992, Wegw \& Long 1995), mammals (Costa et al. 2000) and butterflies (Brown \& Freitas 2000). Unfortunately, there is no study evaluating this trend for leaf-litter frog communities which restrains us from making comparisons. Supposedly, the low species richness of the Salto Morato forest compared to the most northward forests in the biome (e.g., Giaretta et al. 1999, Rocha et al. 2007) can be attributed to latitudinal differences which, in turn, may reflect less favorable climatic conditions, especially during seasons as winter. In fact, in Salto Morato forest, species richness, composition and densities of leaf litter frogs varied among seasons (see below), with winter accounting for nearly half (four species) of that found during the summer (seven species).

All frogs species recorded in the study area were endemic to the Atlantic Rainforest biome and most of them have wide distribution throughout this biome (Frost 2010), with some species occurring in leaf-litter frog communities in southeastern Brazil forests (GiaretTA et al. 1997, 1999, RосHA et al. 2000, 2007, Van Sluys et al. 2007, Almeida-Gomes et al. 2008, Siqueira et al. 2009).

Our data showed that the parameters of leaf-litter frog community of Salto Morato forest varied among seasons. The highest values recorded in spring and summer on leaf-litter frog community parameters, as species richness, abundances and densities, can be appreciated in table I. Thus, as evidenced by the NMDS ordination, there was clustering between spring and summer, which indicates that the parameters of leaf-litter frog community in these seasons are similar, indicating an influence of seasonality in the leaf-litter frog community of the studied area. Seasonal variation in leaf-litter frogs communities has also been reported in other studies in Brazil (GIARETTA et al. 1999), South America (Tоғт 1980a) Central America (Tоғт 1980b, Watling \& Donnelly 2002), and Asia (Watanabe et al. 2005), although the knowledge regarding this trend for tropical forests is still limited. In Paraná, seasonal variation in frog species composition was found in three studies (CONTE \& Machado 2005, Conte \& Rossa-Feres 2006, 2007), however the authors focus on arboreal, terrestrial and semi-arboreal and aquatic species frog communities, not considering the leaf-litter frog community.

Our data showed that the community of leaf-litter frogs in Reserva Salto Morato were affected by air temperature but not by air humidity. Air temperature explained approximately $10 \%$ of the variation in frog density and occurrence, which indicates that other environmental factors also act conjunctly to affect in an important way these community parameters. In tropical forests with wet and dry seasons defined, the precipitation affects significantly the abundance and diversity of frog species living in leaf litter (Allmon 1991, Vonesh 2001). In our study area, we observed high rainfall rates and no clear dry season (FBPN 1995). This fact may explain in part as air temperature appears to explain partially seasonal variation in the community of litter frogs at Salto Morato Reserve, whereas air humidity effect did not appear.

The two most abundant species, $I$. guentheri and $L$. gr. marmoratus, accounted for $37 \%$ and $31 \%$ of the total number of frogs recorded, respectively, suggesting that these two frogs are the dominant species in the local leaf-litter frog community of the area studied. However, it seems to be a trend on communities of leaf-litter frogs being dominated by one to three species belonging to Brachycephalidae and Leptodactylidae families (e.g., GiaretTa et al. 1997, 1999, Rocha et al. 2000, VAN Sluys et al. 2007, Siqueira et al. 2009). In the present study $B$. hermogenesi (third most abundant species) was recorded for the first time in Paraná, extending its distribution to $120 \mathrm{~km}$ south of Ribeirao Grande and $130 \mathrm{~km}$ southwest of the Juréia-Itatins, both localities in the state of São Paulo. The rarer species in the leaf-litter frog community studied was $R$. abei (0.19 ind/ $100 \mathrm{~m}^{2}$ ), suggesting that relatively large bodied frogs tend to occur in smaller numbers in leaf-litter frog community. In fact, Rосна et al. (2007) studying a leaf-litter frog community in a forest at the state of Rio de Janeiro (Reserva de Guapiaçu) suggested a biological trend on the relationship between frog specific body size and their respective abundances in the forest floor. 
Densities of frogs in this study $\left(3.73\right.$ ind $\left./ 100 \mathrm{~m}^{2}\right)$ was lower compared to other studies in Atlantic Forest areas in South America (Giaretta et al. 1999, 4.6 ind/100 m²; Rocha et al. 2001, 5.9 ind $/ 100 \mathrm{~m}^{2}$; RосHa et al. 2007, 8.43 ind $/ 100 \mathrm{~m}^{2}$; AlmeidaGomes et al. 2008, $4.5 \mathrm{ind} / 100 \mathrm{~m}^{2}$; and Siqueira et al. 2009, 17.1 ind/100 $\mathrm{m}^{2}$ ) and in Amazon forest (AlLmon 1991, $4.76 \mathrm{ind} / 100$ $\mathrm{m}^{2}$ ). However, density was higher than those found by GiaretTA et al. (1997), $1.4 \mathrm{ind} / 100 \mathrm{~m}^{2}$, - although, these authors sampled during the dry/cold season, which may have contributed to the low density of frogs they found. The leaf litter frog density values at Salto Morato forest were also lower when compared with other forests in the world, as areas in Costa Rica (LiEBERMAN 1986, 13.2 ind/100 $\mathrm{m}^{2}$ ), Panama (ToFт $1980 \mathrm{~b}, 11.8 \mathrm{ind} / 100 \mathrm{~m}^{2}$ ) and Cameroon (Sсотт 1982, 9.4 ind $/ 100 \mathrm{~m}^{2}$ ), but higher than those recorded in Borneo (LLoyd et al. 1968, $1.09 \mathrm{ind} / 100 \mathrm{~m}^{2}$ ) and Thailand (INGer \& Colwell 1977, 0.55 ind $/ 100 \mathrm{~m}^{2}$ ).

One additional factor that may have contributed for the low overall density of leaf-litter frogs in the Reserva Salto Morato may be the altitude of the study area (between 200 and $300 \mathrm{~m}$ altitude). Although there are few studies addressing to the effect of altitude on the composition of communities of leaflitter frogs in the Atlantic Forest, there may be a trend towards a greater density of frogs in high altitudes, where conditions are apparently more favorable, as pointed out by GIARETTA et al. (1997, 1999), in two studies in São Paulo, and by Rocha et al. (2007) and Siqueira et al. (2009) in the state of Rio de Janeiro. Data available regarding leaf-litter frog abundances in the Atlantic Rainforest biome (see references above) showed that overall frog density in the leaf-litter of forest floor is markedly variable among areas even within a same biome. This variation probably reflect differences among areas in the structural environment, in the availability of resources, in the climatic conditions and in latitude, although we still need a large number of studies on this subject to better understand the trends affecting this variation.

The leaf litter frog biomass ( $\mathrm{g} / \mathrm{ha}$ ) in the community also varied among seasons. However, three individuals $R$. abei, anuran with large body proportions, considerably contributed to autumn estimated mass, resulting, in this season, in biomass values reaching the highest value among the four studied seasons. Excluding the individuals of this toad species, a similar tendency of abundance into all the other species can be observed, suggesting that the biomass in the leaf litter-frog community is also higher during warmer months (spring and summer).

We conclude that the community of leaf-litter frogs in the Reserva Salto Morato varies among seasons, with lower values of abundance, density and richness in cooler seasons. The higher latitude of the area in the present study compared to those where other studies in the tropics regarding leaf-litter frogs were made, may explain in part why values of the community parameters were comparatively lower than those found for leaf-litter frogs in other forests in Brazil and worldwide. We therefore emphasize the importance of extending studies that address seasonal effects on communities of leaf-litter frogs.

Our study is the first providing data on the composition, richness, abundances and densities of the leaf-litter frog community for the Reserva Natural Salto Morato, as well as the first study regarding this subject to the extensive region of southern Brazil, including Paraná. Also, this study is the first providing data regarding seasonal variation in a leaf-litter frog community to southern forests of Brazil. The few studies in Paraná regards amphibian species composition for two areas (Armstrong \& Conte 2010, Cunha et al. 2010).

\section{ACKONWLEDGMENTS}

This study was sponsored by Conselho Nacional de Desenvolvimento Científico e Tecnológico (CNPq), which provided research grants to C.F.D. Rocha (Processes 304791/20105 and 470265/2010-81. Graduate fellowships were granted to M.S. Pereira from the Coordenação de Aperfeiçoamento de Pessoal de Nível Superior (CAPES). Authorization 20703-3 to collect the frogs was granted by Instituto Chico Mendes de Conservação da Biodiversidade (ICMBio). We also thank the Reserva Natural Salto Morato for logistical support during the study, and A.L. Benedeti, A.L. Luza and L.F.W. Bortolon for their support during the inventories and M. Almeida-Gomes, M. Wachlevski and R. C. Laia for kindly reviewing the manuscript.

\section{LITERATURE CITED}

Allmon, W. D. 1991. A plot study of Forest floor litter frogs, Central Amazon, Brazil. Journal Tropical Ecology 7: 503522.

Almeida-Gomes M., D. Vrcibradic, C. C. Siqueira, M. C. Kiefer, T. Klaion, P. Almeida-Santos, D. Nascimento, C. V. Ariani, V. N. T. Borges, R. F. Freitas, M. Van Sluys \& C.F. D. Rocha. 2008. Herpetofauna of an Atlantic rainforest area (Morro São João) in Rio de Janeiro State, Brazil. Anais da Academia Brasileira de Ciências 80: 291-300.

Armstrong, C.G. \& C.E. Conte. 2010. Taxocenose de anuros (Amphibia: Anura) em uma área de Floresta Ombrófila Densa no Sul do Brasil. Biota Neotropica 10 (1): 39-46.

Benítez-Malvido, J. \& M. Martinez-Ramos. 2003. Impact of Forest Fragmentation on Understory Plant Species Richness in Amazonia. Conservation Biology 17 (2): 389-400.

Brown K.S. \& A.V.L. Freitas . 2000. Diversidade de lepidópteros em Santa Teresa, Espírito Santo. Boletim do Museu de Biologia Mello Leitão 11 (12): 71-116.

Brown, W. C. \& A.C. AlCala. 1961. Populations of amphibians and reptiles in the submontane and montane forests of Cuernos de Negros, Phillipine Islands. Ecology 42: 628-636.

Clarke, K.R. 1993. Non-parametric multivariate analyses of changes in community structure. Australian Journal of Ecology 18: 117-143. 
Collar N.J.; L.P. Gonzaga; N. Krabbe; A. Madroño-Nieto; L.G. Naranjo; T.A. Parker III \& D.C. Wege. 1992. Threatened birds of the Americas: The ICBP/IUCN Red Data Book. Washington, DC, Smithsonian Institution Press, $3^{\text {rd }}$ ed., 1150p.

Conte, C.E. \& R.A. Machado. 2005. Riqueza de espécies e distribuição espacial e temporal em comunidade de anuros (Amphibia, Anura) em uma localidade de Tijucas do Sul, Paraná, Brasil. Revista Brasileira de Zoologia 22 (4): 940:948.

Conte, C.E. \& D.C. Rossa-Feres. 2006. Diversidade e ocorrência temporal da anurofauna (Amphibia, Anura) em São José dos Pinhais, Paraná, Brasil. Revista Brasileira de Zoologia 23 (1): 162-175.

Conte, C.E. \& D.C. Rossa-Feres. 2007. Riqueza e distribuição espaço-temporal de anuros em um remanescente de Floresta de Araucária no sudeste do Paraná. Revista Brasileira de Zoologia 24 (4): 1025-1037.

Costa L.P.; Y.L.R. Leite Y.L.R.; G.A.B. Fonseca \& M.T. Fonseca. 2000. Biogeography of South American forest mammals: endemism and diversity in the Atlantic Forest. Biotropica 32: 872-881.

Cunha, A.K.; I.S. Oliveira; M.T. Hartmann. 2010. Anurofauna da Colônia Castelhanos, na Área de Proteção Ambiental de Guaratuba, Serra do Mar paranaense, Brasil. Biotemas 23 (2): 123-134.

Faith, D.P.; P.R. Minchin \& L. Belbin. 1987. Compositional dissimilarity as a robust measure of ecological distance. Vegetatio 69: 57-68.

Fauth, J.E.; B.I. CRother \& J.B. Slowinski. 1989. Elevational patterns of species richness, evenness, and abundance of the Costa Rica leaf-litter herpetofauna. Biotropica 21: 178-185.

FBPN. 1995. Reserva Natural Salto Morato - Plano de Manejo. São José dos Pinhais, Fundação O Boticário de Proteção à Natureza, 80p.

Frost, D.R. 2010. Amphibiam Species of the World: An Online Reference. New York, American Museum of Natural History, version 5.4, Available online at: http://research.amnh.org/ vz/herpetology/amphibia/index.php [Accessed: 19/X/2010].

FundaÇ̃̃o SOS MATA ATLÂNTICA. 1998. Atlas da evolução dos remanescentes florestais e ecossistemas associados no Domínio da Mata Atlântica no período de 1990-1995. São Paulo, Fundação SOS Mata Atlântica, Instituto Nacional de Pesquisas Espaciais, Instituto Sócio-Ambiental, Relatório Nacional, 7p.

Gardner, T.A.; M.A. Ribeiro-Júnior; J. Barlow; T.C.S. Ávila-Pires; M.S. Hoogmoed \& C.A. Peres. 2007. The Value of Primary, Secondary, and Plantation Forests for a Neotropical Herpetofauna. Conservation Biology 21 (3): 775-787.

GASCON, C. 1996. Amphibian litter fauna and river barriers in flooded and non-flooded Amazonian rain forests. Biotropica 28: 136-140.

Giaretta, A.A.; R.J. Sawaya; G. Machado; M.S. Araújo; K.G. Facure; H.F. Medeiros \& R. Nunes. 1997. Diversity and abundance of litter frogs an altitudinal sites at Serra do Japi, Southeastern Brazil. Revista Brasileira de Zoologia 14 (2): 341-346.
Giaretta, A.A.; K.G. Facure; R.J. Sawaya; J.H.D. Meyer \& N. Chenin. 1999. Diversity and abundance of titter frogs in a montane forest of southeastern Brazil: Seasonal and altitudinal changes. Biotropica 31 (4): 669-674.

HadDad, C.F.B. \& I. Sazima. 1992. Anfíbios anuros da Serra do Japi, p. 188-211. In: L.P.C. Morellato (Ed.). História Natural da Serra do Japi: Ecologia e Preservação de uma Área Florestal no Sudeste do Brasil. Campinas, Editora Unicamp.

Haddad, C.F.B.; L.F. Todelo \& C.P.A. Prado. 2008. Anfíbios da Mata Atlântica: guia dos anfíbios anuros da Mata Atlântica. São Paulo; Editora Neotropica; 244p.

Heyer W.R.; A.S. Rand; C.A.G Cruz; O.L. Peixoto \& C.E. Nelson. 1990. Frogs of Boracéia. Arquivos de Zoologia 31 (4): 231410.

INGER, R. F. \& R.K. Cowell. 1977. Organization of contiguous communities of amphibians and reptiles in Thailand. Ecological Monographs 47 (3): 229-253.

Lieberman, S.S.1986. Ecology of the litter herpetofauna of a Neotropical Rain Forest: La Selva, Costa Rica. Acta Zoologica Mexicana 15 (1): 1-71.

Lloyd, M.; R.F. Inger \& F. WAYne-KIng. 1968. On the diversity of reptile and amphibian species in a Bornean Forest. American Naturalist 102 (928): 497-515.

Machado, R.A.; P.S. Bernarde; S.A.A. Morato \& L. Anjos. 1999. Análise comparada da riqueza de anuros entre duas áreas com diferentes estados de conservação no município de Londrina, Paraná, Brasil (Amphibia, Anura). Revista Brasileira de Zoologia 16 (4): 997-1004.

Myers N.; R.A. Mittermeier; C.G. Mittermeier \& G.A.B. Fonseca. 2000. Biodiversity hotspots for conservation priorities. Nature 403 (6772): 853-858.

Pombal Jr, J.P. \& M. Gordo. 2004. Anfíbios Anuros da Juréia, p. 243-256. In: (O.A.V. Marques \& W. Duleba (Eds). Estação Ecológica Juréia-Itatins. Ambiente Físico, Flora e Fauna. Ribeirão Preto, Holos Editora.

Quintela, C.E. 1990. An S.O.S. for Brazil's beleaguered Atlantic Forest. Nature Conservation Magazine 40 (2): 14-19.

Ribeiro, M.C.; J.P. Metzger; A.C. Martenses; F.J. Ponzoni \& M.M. Hirota. 2009. The Brazilian Atlantic Forest: How much is left, and how is the remaining forest distributed? Implications for conservation. Biological Conservation 142: 1141-1153.

Rocha, C.F.D.; M. Van Sluys; M.A.S. Alves; H.G. Bergallo \& D. VRCibradic. 2000. Activity of leaf-litter frogs: when shoud frogs be sampled? Journal of Herpetology 34 (2): 285-287.

Rocha, C.F.D.; M. Van Sluys; M.A.S. Aalves; H.G. Bergallo \& D. VRCIBRADIC. 2001. Estimates of forest floor litter frog communities: A comparison of two methods. Austral Ecology 26 (1): $14-21$.

Rocha, C.F.D; D. Vrcibradic; M.C. Kiefer; M. Almeida-Gomes; V.N.T. Borges-Junior; P.C.F. Carneiro; R.V. Marra; P. Almeida-Santos; C.C. Siqueira; P. Goyannes-Araújo; C.G.A. Fernandes; E.C.N. RuBião \& M. VAN SLUYS. 2007. A survey of the leaf-litter frog assembly from an Atlantic forest area (Reserva Ecológica de 
Guapiaçu) in Rio de Janeiro State, Brazil, with an estimate of frog densities. Tropical Zoology 20 (1): 99-108.

SBH. 2010. Lista de espécies de anfíbios do Brasil. Sociedade Brasileira de Herpetologia, available on line at: http://sbherpetologia.org.br/checklist/anfibios.htm [Accessed: 19/X/2010].

Scotт, D.A. \& M.L. Brooke. 1985. The endangered avifauna of Southeastern Brazil: A report on the BOU/WWF expeditions of 1980/81 and 1981/82, p. 115-139. In: A.W. Diamond \& T.E. Lovejoy (Eds). Conservation of Tropical Forest Birds. Cambridge, ICBP, Technical Publication \#4, 324p.

Scotт-JR, N.J. 1976. The abundance and diversity of the herpetofauna of tropical forest litter. Biotropica 8 (1): 41-58.

Sсотт JR, N.J. 1982. The herpetofauna of forest litter plots from Cameroon, p. 145-150. In: N.J. SсоTT JR (Ed.). Herpetological Communities: A Symposium of the Society for the Study of Amphibians and Reptiles and the Herpetologists' League, August 1977. Fish and Wildlife Service, Wildlife Research Report 13.

Siqueira, C.C.; D. VRCibradic; M. Almeida-Gomes; V.N.T. Borges-Junior; P. Almeida-Santos; M. Almeida-Santos; C.V. Ariani; D.M. Guedes; P. Goyannes-Araújo; T.A. Dorigo; M. Van Sluys \& C.F. Rocha. 2009. Density and richness of leaf litter frogs (Amphibia: Anura) of na Atlantic Rainforest área in the Serra dos Órgãos, Rio de Janeiro State, Brazil. Zoologia 26 (1): 97-102.

Straube, F.C. \& A. Urben-Filho. 2005. Avifauna da Reserva Natural Salto Morato (Guaraqueçaba, Paraná). Atualidades Ornitológicas 124: 12-32.

Todd, B.D. \& K.M. Andrews. 2007. Response of a Reptile Guild to Forest Harvesting. Conservation Biology 22 (3) 753-761.
Toғт, C.A. 1980a. Feeding ecology of thirteen syntopic species of anurans in a seasonal tropical environmental. Oecologia 45: 131-141.

ToFT, C.A. 1980b. Seasonal variation in populations of panamanian litter frogs and their prey - a comparison of wetter and drier sites. Oecologica 47: 34-38.

Van Sluys, M.; D. Vrcibradic; M.A.S. Alves; H.G. Bergallo \& C.F.D. Rосна. 2007. Ecological parameters of the leaf-litter frog community of an Atlantic Rainforest area at Ilha Grande, Rio de Janeiro state, Brazil. Austral Ecology 32 (3): 254-260.

VANZOLINI P.E. 1988. Distributional patterns of South American lizards, p. 317-342. In: P.E. VAnzolini \& W.R. Heyer (Eds). Proceedings of a Workshop on Neotropical Distributional Patterns. Rio de Janeiro, Academia Brasileira de Ciências, 488p. Vonesh, J.R. 2001. Patterns of richness and abundance in a tropical African leaf-litter herpetofauna. Biotropica 33 (3): 502510.

Watanabe, S.; N. Nakanishi \& M. IzaWa. 2005. Seasonal abundance in the floor-dwelling frog fauna on Iriomote Island of the Ryukyu Archipelago, Japan. Journal of Tropical Ecology 21 (1): 85-91.

Watling, J.I. \& M.A. Donnelly. 2002. Seasonal patterns of reproduction and abundance of leaf litter frogs in a Central American rainforest. Journal of Zoology 258 (2): 269-276.

WEGE, D.C. \& A.J. Long. 1995. Key areas for threatened birds in the neotropics. BirdLife Conservation Series 5: 75-80.

WiLKINSON, L. 2004. Systat, Version 11.0. San José, Software Inc. ZAR, J.H. 1984. Biostatistical analysis. Inglewood Cliffs, Prentice-Hall, $2^{\text {nd }}$ ed., 718p.

Submitted: 17.XI.2010; Accepted: 25.X.2011.

Editorial responsibility: Mauricio O. Moura 